\title{
Energy Utilization in Crop and Dairy Production in Organic and Conventional Livestock Production Systems
}

\author{
Karen Refsgaard, ${ }^{a *}$ Niels Halberg ${ }^{b}$ \& Erik Steen Kristensen ${ }^{b}$ \\ ${ }^{a}$ Department of Economics and Social Sciences, Agricultural University of Norway, \\ PO Box 5033, N-1432 Aas, Norway \\ ${ }^{b}$ Danish Institute of Agricultural Science, PO Box 50, DK-8830 Tjele, Denmark
}

(Received 22 April 1996; accepted 30 November 1997)

\begin{abstract}
$A B S T R A C T$
Searching for livestock production systems with a high energy utilization is of interest because of resource use and pollution aspects and because energy use is an indicator of the intensification of production processes. Due to interactions between crop and livestock enterprises and between levels of different input factors and their effects on yields, it is proposed to analyze agricultural energy utilization through system modelling of data from farm studies. Energy use in small grains, grass-clover and fodder beets registered in organic and conventional mixed dairy farms was analyzed and used together with crop yields in order to model energy prices on three Danish soil types. Conventional crop yields were higher but they also used more indirect energy with input factors, especially fertilizers. The conventional yields were not sufficiently higher to compensate for the extra use of energy compared with the organic crops. The organic crops had lower energy prices on all soil types, with the smallest difference on irrigated sandy soils. Sensitivity analyses were made for the effects of changes in irrigation and fertilizer levels. One conclusion was that better energy utilization in grain crops might be found at intermediate levels of fertilizer use, especially on irrigated soils. Actual farm diesel use was on average $47 \%$ higher than expected from standard values, suggesting that care should be taken when basing energetic analysis of farming methods on experimental data alone. On the same farms, the energy use in dairy production registered in
\end{abstract}

*To whom correspondence should be addressed. Norwegian Agricultural Economics Research Institute, PO Box 8024 Dep, N-0030 Oslo, Norway. Tel.: 00472217 35 40; fax: 00 47221735 38; e-mail: karen.refsgaard@nilf.nlh.no 
organic and conventional mixed dairy farms was analyzed and used together with milk and meat yields in order to model energy prices for three different feeding strategies and two soil types. Conventional dairy production is more intensive with a greater feeding ration and a higher proportion of high-protein feed, but has also higher yields. The conventional yields were not sufficiently higher to compensate for the extra use of energy compared with the organic feeding ration. However, the lower energy price in organic dairy production is dependent on the composition of the feeding strategy. Substitution of $500 S F U$ of grain with grass pellets makes an ordinary organic feeding ration based on conventional crop production competable. In general, the crop energy price models can be used together with the dairy production to model the effects of different feeding and crop rotation strategies on the overall energy utilization in mixed dairy production systems. (C) 1998 Elsevier Science Ltd. All rights reserved

\section{INTRODUCTION}

Today's agricultural production relies heavily on the consumption of nonrenewable fossil fuels. Consumption of fossil energy results in direct negative environmental effects through release of $\mathrm{CO}_{2}$ and other combustion gases. Indirectly, there have been positive effects: increased yields and reduced risk. Yet large amounts of cheap fossil energy have indirect negative impacts on the environment, such as less diversified nature through the intensification of agricultural practices. Thus, looking for agricultural production methods with a higher energy productivity is as topical today as it was some 20 years ago (Pimentel et al., 1973). According to the Brundtland Commission, the total consumption of energy has to be reduced $50 \%$ before 2035 .

To cite Giampietro et al. pp. 30 (1994), "In agriculture, energy analysis can be used to assess the impact of human activity on the complexity and stability of environmental equilibria in terms of alteration of patterns of energy flows."

We use fossil energy utilization analysis to evaluate the energy conversion and resource use of different mixed dairy production systems in Denmark. The total direct and indirect energy use in the primary agricultural sector alone (i.e. to the farm gate) was about $18 \%$ of the total energy consumption in Denmark in 1982-83 (Parsby and Fog, 1984).

It is not obvious how the energy utilization would be influenced by a change in production intensity, as reduced yields might counterbalance any energy savings from reducing external inputs. Wagstaff (1987) suggests on the basis of a literature review "that within mechanised farming in industrialized countries it is unlikely that substantial energy savings would result solely from a reorientation towards systems characterized by lower external current inputs." The use of fertilizers and pesticides, for instance, has an 
impact on fodder crop yields as well as indirect energy consumption (fossil fuel used for their manufacturing). As most dairy farms are net fodder importers, any shift in crop yields has consequences for the fodder importanother source of indirect energy - as well as the crop rotation. Any restrictions imposed in a part of a farming system might be substituted for in other parts of the system by the farm manager. Therefore, it is an interesting and complex question whether less intensive dairy farming systems are more energy efficient than conventional systems.

Because of the interactions between crop and husbandry enterprises, we find that these questions might best be researched by systems modelling (Sørensen and Kristensen, 1993) based on studies of private farms. To facilitate modelling of different strategies, separate models for crop and livestock production are developed.

Organic farming was developed by farmers concerned about resource utilization and environmental effects. Pimentel (1993) and Pimentel et al. (1983) have proposed that organic production methods have a better energy utilization in many crop entcrprises (c.g. in wheat and maize). Therefore, thesc might be feasible critical cases for the study of less intensive farming methods.

The aim of this paper is, on the basis of farm studies:

1. to analyze and model the energy consumption and productivity in organic and conventional cropping and dairy systems;

2. to discuss different strategies to improve the energy utilization in crop and husbandry production systems.

\section{METHODS AND MATERIALS}

\section{Principles for energy utilization}

Similar to the economist's cost, energy carries a price tag. It has an actual or potential use as a resource and, by using it, one incurs an opportunity cost, in the sense that one cannot use the resource in another way. This implies a concern for resource depletion. Here, we exclude the vast energy flux of the sun. Not because of usefulness, but because no stock is depleted: no opportunity cost is incurred (Leach, 1976).

The two major substitutes for fossil energy in agricultural production are solar and human energy. The sun and the fossil fuels differ in their patterns of scarcity.

Radian-energy from the sun is practically infinite in total amount (stock), but it is strictly limited in its flow rate. Conversely, energy stored in fossil fuels and minerals is strictly limited in its total amount in a very long 
perspective (stock), but relatively unlimited in its flow rate-that is, we can use it up at a rate largely of our own choosing (Daly and Cobb, 1989).

Solar energy is indirectly brought into the agricultural production system through crop production, with land acting as a solar collector. The highest quality soils require less human and fossil energy inputs per unit of food produced than the poorer soils. Yet food production can be increased markedly in the short term by investing more energy (Jones, 1989; Hall et al., 1992; Pimentel et al., 1994).

The other substitute for fossil energy is human energy or labour, but this input is hard to convert to energy figures for obvious reasons. Energy costs might include energy for food for the specific work done and for the maintenance of the body. One might also include other needs for labour as a member of society. Moreover, labour contributes not only with physical work but also with intellectual work, which is difficult to quantify (Nielsen and Rasmussen, 1977; Pimentel, 1980; Jones, 1989). Labour and fossil energy are too different to be handled with the same term, and therefore labour energy is not included in our analysis.

In our study, we use process analysis (Fluck, 1992), which is defined as the evaluation of both direct energy inputs and all indirect energy inputs (Fig. 1). The direct energy refers to the fuel burned at the site of production, corresponding to the items inside the farm borderline (Fig. 1). The indirect energy refers to fuel burned in other sectors to manufacture the materials purchased and used as inputs at the site of production (e.g. energy for production of mineral fertilizer), corresponding to the items outside the borderline of Fig. 1.

The more indirect the energy cost becomes for the farm, the smaller the contribution to the total energy cost of the agricultural product. Setting the right system boundary is difficult. What about the energy used for the production of the inventory used at the fertilizer plants, for instance? In general, roughly half of the embodied energy of a good or service is used at the site of production (Hall et al., 1992). Nielsen and Rasmussen (1977) report that the last two stages of a production process in general will cover more than $90 \%$ of total fossil energy input. Therefore, to avoid this infinite regression we only include the indirect energy costs one step backwards from the farm. Even though the energy used to manufacture capital goods for producing farm inputs thus is excluded, our study will presumably cover over $90 \%$ of the energy used in the whole production process.

\section{The energy price}

Energy price is the quantity of energy required per unit yield for a given agricultural product. It is proposed as a measure for the utilization of energy 


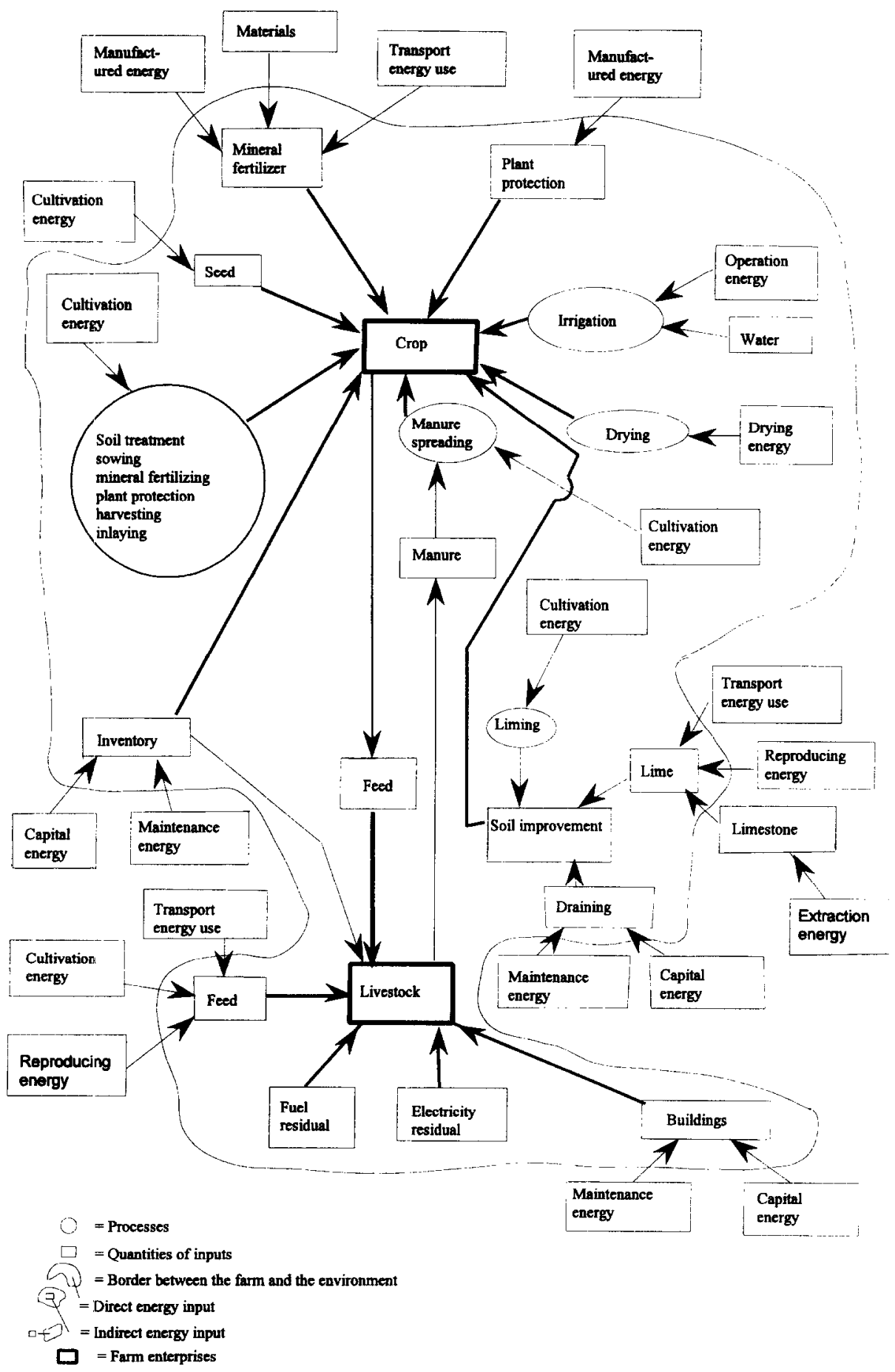

Fig. 1. A conceptual model for the use and conversion of fossil energy on a livestock farm. 
in industrialised agricultural systems (Fluck, 1979). The resource use is related to the quantity of output from the production system as a measure for the utilization of fossil energy. Measuring the output in human feed units is not straightforward because of the disparate qualities of the food produced.

\section{Data}

Data on 14 organic and 17 conventional farms affiliated with the Danish Institute of Animal Science were recorded during the 2-year period from 1 May 1990 until 30 April 1992 for the direct energy input. Yields and input quantities were registered during the 4-year period from 1 May 1989 until 30 April 1993.

All farms have dairy production (except two organic farms with beef cattle) as the main enterprise, combined with grain production. Organic farms meet the Danish organic regulations prohibiting the use of chemically produced fertilizers and pesticides. Non-organically produced fodder, only of Danish production, is limited to $15 \%$, and organic animal manure is applied from, at most, 1.4 livestock units $\mathrm{ha}^{-1}$ year $^{-1}$.

The goal of data collection is to describe the triple flow of energy, nutrients and money on each farm. Information is collected at farm, herd and crop level. Data are collected from biweekly visits recording fodder consumption over a 24-h period, stocks assessments, farm purchases, and sales and input for crops. All registered inputs and yields are checked yearly against the farms accounts, and any private consumption of diesel and electricity is separated from the amounts used in the production. A detailed description of each farm's production system and yield during the working years is presented in yearly publications (Østergaard, 1990, 1991; Kristensen and Østergaard, 1992; Kristensen, 1993).

There are some differences between organic and conventional farms regarding soil type and partition of crops and livestock units per hectare, (Table 1). The number of livestock units per hectare is $40 \%$ greater on conventional farms due to difference in breeds and fattening of bull calves. The area with fodder bects and wholc crop silage from small grains is higher on conventional farms, whereas the organic farms have more grass-clover in rotation, including $9 \%$ lucerne. The crops on the remaining area are different types of cereals (including about $10 \%$ winter cereals) and other cash crops such as potatoes and rape seed. The proportion of grass-clover harvested for silage is on average greater on the organic farms; but the area of permanent pasture is nearly identical for the two farming systems (11-12\%).

The organic dairy farms sell on average a larger proportion of animal products compared with plant products than conventional dairy farms- $-\mathrm{a}$ result of the production rules for the organic system. 
TABLE 1

Some Characteristics for the Analyzed Project Farms

\begin{tabular}{lcc}
\hline & \multicolumn{2}{c}{ System } \\
\cline { 2 - 3 } & Conventional & Organic \\
\hline Number of farms & 17 & 14 \\
Distribution regarding: & & $7+7$ \\
$\quad$ Soil type: sandy + clay & $14+3$ & $4+10$ \\
Irrigation: yes + no & $9+8$ & \\
Average & & $71(21-114)$ \\
Area (ha) & $56(25-85)$ & $11(0-32)$ \\
Permanent pasture (\%) & $12(0-51)$ & $40(28-59)$ \\
Rotation clover-grass/lucerne (\%) & $26(0-63)$ & $4(0-10)$ \\
Fodder beets (\%) & $10(0-27)$ & $9(0-18)$ \\
Whole crop silage (\%) & $16(0-49)$ & $41(16-50)$ \\
Grain for harvest (\%) & $32(0-56)$ & $4(0-13)$ \\
Other cash crops (\%) & $3(0-20)$ & $1.06(0.8-1.5)$ \\
Average livestock units ha ${ }^{-1} a$ & $1.5(1.27-2.26)$ & \\
\hline
\end{tabular}

Units in parentheses represent minimum and maximum values, respectively.

${ }^{a}$ Livestock unit is equal to one dairy cow of approximately $550 \mathrm{~kg}$.

\section{System modelling}

Simple relations between the level of individual input factors, cultivation methods or feeding strategy, and energy utilization across farms cannot be expected because different input factors and methods may substitute for each other. Furthermore, the inputs, yields and energy prices are a consequence of complex relations between management and biological processes.

Because of the unbalanced partition of soil types and irrigation between the organic and conventional farms, we cannot correct for soil type and irrigation by statistical means. Therefore, models of energy use in five conventional and organic crops on three soil types are developed as illustrated in Fig. 2.

For each crop model, we analyze the input for the effect of production system and soil type. The term 'soil type' includes three classes: (1) clay soils and (2) sandy soils with and (3) without possibility for irrigation as defined in Halberg and Kristensen (in press). Further, we test for the dependency of manure type, harvesting method and yield quantity.

Since the data from the 2 (the data concerning use of direct energy, inventory and buildings) and 4 (the data concerning biological input and output) working years on the same farm are assumed not to be statistically independent, the analysis is performed using average data for each farm. 


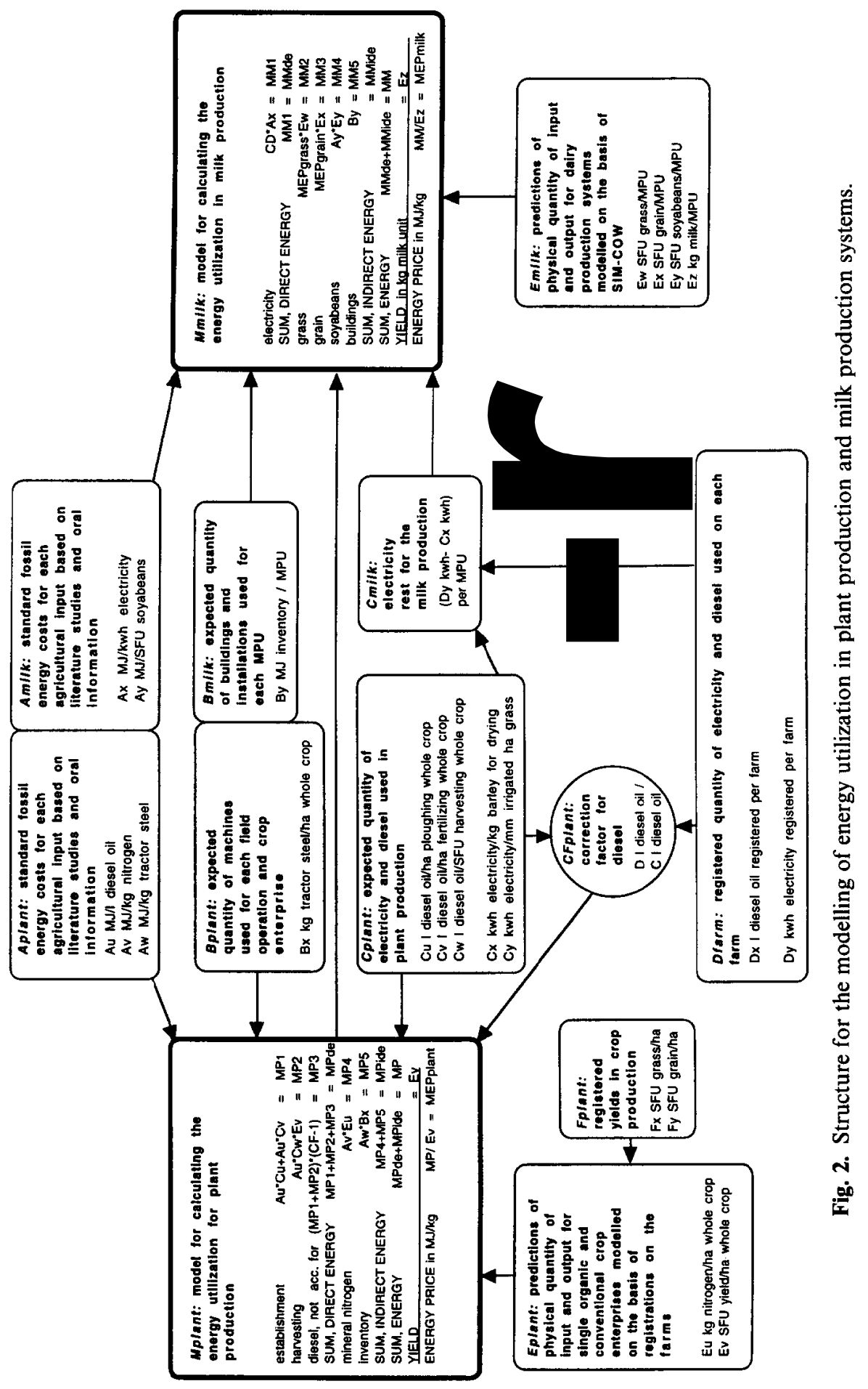


The main elements for the crop models are illustrated in Fig. 2 as the parts related to $M_{\text {plant }}$. The main elements for the milk production are shown as the parts related to $M_{\text {milk }}$.

1. $A_{\text {plant }}+A_{\text {milk: }}$ : standard fossil energy costs for each agricultural input based on literature studies and personal communication.

2. $B_{\text {plan }}$ : expected quantity of machines used for each field operation and crop enterprise.

3. $B_{\text {milk }}$ : expected quantity of buildings and installations used for each milk producing unit (MPU).

4. $C_{\text {plant }}$ : expected quantity of electricity and diesel used for the plant production.

5. $C_{\text {milk: }}$ : quantity of electricity left for the milk production.

6. $C F_{\text {plani }}$ : correction factor for diesel.

7. $D_{\text {farm: }}$ : registered quantity of electricity and diesel used on each farm.

8. $E_{\text {plant }}:$ predictions of physical quantity of input and outputs for single organic and conventional crop enterprises, modelled on the basis of registrations on the farms.

9. $E_{\text {milk }}$ : predictions of physical quantity of input and output for dairy production systems derived from the model SIM-COW.

10. $F_{\text {plant }}:$ registered yields in crop production.

11. $M_{\text {plant }}$ : model for calculating the energy utilization for plant production.

12. $M_{\text {milk }}:$ model for calculating the energy utilization in milk production.

$A_{\text {plant }}+A_{\text {milk }}$

The calculations are based on information about real consumption of primary and secondary energy 'carriers', mainly coal, oil and electricity in the agro-industrial complex.

The energy used for the manufacture of the single crop inputs is calculated on the basis of an average quantity of energy per quantity of farm input for the most important manufacturing firms. ${ }^{\dagger \ddagger \$}$ For some items, however, several

\footnotetext{
${ }^{\dagger}$ Mineral nitrogen composes the major part of the indirect energy cost for the conventional cropping systems and has an energy cost of $38 \mathrm{MJ} \mathrm{kg}^{-1}$ in our models (Refsgaard, 1992). This is a low figure compared with Schroll (1994), but according to Parsby and Fog (1984) and Fluck (1992) there has been a great improvement in the energy productivity, and the practical minimum has nearly been reached in the processes used in Western Europe today, especially in Norway (Bøckman et al., 1991).

†Phosphorus is also an energy expensive input, but because the quantity used is small compared with nitrogen the importance is negligible.

${ }^{\S}$ Investigations by Refsgaard (1992) showed an average of $0.21 \mathrm{MJ} \mathrm{kg}^{-1}$ limestone, which is only $10 \%$ of the value used by Nielsen and Rasmussen (1977).
} 
similar inputs exist, produced with different technology, at different factories, at different geographical places, or in joint production with other products. Resource constraints vary greatly between countries, and what is economically 'efficient' in one place may not be in another (Leach, 1976). Where production of inputs occurs at different places, National Account Statistics are used to estimate the energy use for transport with respect to quantity. If joint production processes occur and the energy input for every specific product cannot be found, and no typically main product exists, then the energy cost for, say, feed is distributed with respect to the feeding value. If a typical main product exists, then the by-products are given only the extra cost they lend to. Further details can be found in Refsgaard (1992).

The energy use differs according to transport medium. For example, the energy use for big container ships is about $2 \%$ of the energy use for trailers.

$B_{\text {plant }}+B_{\text {milk }}$

Two principles have been used to calculate energy cost related to machine equipment. We use energy cost per kilogram machinell multiplied by the machine weight and distributed with regard to lifetime and use.**t†

Machines for establishment, sowing and maintenance of the crop with a few exceptions are assumed to be owned by the farmer. For machines and tractors used for harvesting and transport of yields it is assumed (according to the praxis for our case farms) that contractors are hired, and the average use for a specific enterprise is calculated with respect to the total lifetime in hours.

'Big container ships use about $0.04 \mathrm{MJ} \mathrm{t}^{-1} \mathrm{~km}-1$ while trailers use $1.9 \mathrm{MJ} \mathrm{t}^{-1} \mathrm{~km}^{-1}$ (Andersen, personal communication; Hansen, personal communication; Jensen, personal communication; Jørgensen, personal communication; Krejbjerg, personal communication; Danmarks Statistik, 1990a, b).

"The energy cost for inventory of $91.8 \mathrm{MJ} \mathrm{kg}^{-1}$ is based on numbers from Smil et al. (1983) and includes both energy sequestered in manufacturing and energy for repair of farm machinery.

**The standard numbers for weight and lifetime for each machine type were collected from Nielsen (personal communication) and Kjeldahl (personal communication). The average indirect energy used for a specific enterprise was then calculated with respect to lifetime in years (from 10 to 15 ) and with respect to total driven acreage with that machine. For the tractors, the total lifetime was measured in hours and the avcrage use for cach crop cnterprise was calculated on the basis of working capacity for machine operations.

${ }^{\dagger+}$ This principle has also been used by Steinhart and Steinhart (1974), Smil et al. (1983) and Bowers (1992), while Leach (1976) and Nielsen and Rasmussen (1977) related an energy cost to monetary values and then multiplied with the sales price. However, using the weight as the basis follows the principle used for the other energy inputs in our investigation. According to Bowers (1992), the energy cost is primarily related to the amount of steel in a product. Excluding the principle with energy cost related to monetary value also leaves problems with real price out of matter. 
The energy use for buildings and installations were based on standard numbers for demand for room and materials. ${ }^{\ddagger \ddagger}$

$C_{\text {plant }}$

For the direct energy costs, modified standard coefficients are used to distribute an expected quantity of diesel oil and electricity to each registered field operation within the different enterprises. $\$ \S$

The standard coefficients for the diesel consumption in field operations are generally correlated with the area. However, harvesting and transport of crop inputs and yields with a low content of dry matter is correlated with the gross quantities (Nielsen, 1991). 19

An expected quantity of electricity is calculated to be used in the crop system for irrigation and drying of crops. Energy used for irrigation is correlated with the quantity irrigated. The minor part used for drying of crops is correlated to the quantity, the moisture content of grain, the drying temperature and the silo type (Pick et al., 1989). \|\|

The dicsel consumption for handling of animal manure is directly correlated to quantity and related to type of manure, machine type and farm size. ${ }^{* * *}$ The effect of production system is to be seen through the type and composition of manure used in each crop enterprise.

$C F_{\text {plant }}+C_{\text {milk }}+D_{\text {farm }}$

For every farm, a correction factor (CF) is calculated to balance the registered quantity of diesel oil, $D_{\text {farm }}$, to the sum of the expected quantities calculated from standard values for the single enterprises. An average CF over all farms is thereafter multiplied by the sum of the calculated diesel used in the models to give the input 'diesel not accounted for' in each crop.

\footnotetext{
¥†The energy use for buildings and installations was based on Nielsen and Rasmussen (1977). They used $952 \mathrm{kWh}$ corresponding to $3427 \mathrm{MJMPU}^{-1}$. The numbers were based on the energy values for the single items used for building materials.

$\S \S$ The numbers are mainly based on Pick et al. (1989), Nielsen (1991), Nielsen and Larsen (1991) and Birkjær, Høy and Schiønning-Madsen (personal communication). The modifications are done with respect to the registered yield quantities, manure quantities, field distances, irrigation conditions, drying facilities, machine facilities for delivery of manure, use of machine entrepreneurs and some atypical crop operations on the study farms.

กฯAll transport of crop yields and manure is multiplied by a transport correction factor of 1.06 corresponding to an average field distance of $750 \mathrm{~m}$.

"Iil For drying grain from $18 \%$ down to $14 \%$ moisture content, our assumption is $14.5 \mathrm{MJ}$ $100 \mathrm{~kg}^{-1}$ (Jakobsen, personal communication; Nielsen, personal communication).

${ }^{* * *}$ The factor for handling manure is assumed to be 0.41 litre $\mathrm{t}^{-1}$ manure for fluid manure corresponding to an average for machine entrepreneurs, 1.05 litre $t^{-1}$ for handling dry manure, and 1.11 litre $\mathrm{t}^{-1}$ for handling dry composted manure corresponding to an average for the analyzed farms (Kjeldahl, personal communication; Nielsen, personal communication).
} 
An average remaining quantity of the registered quantity of electricity, $D_{\text {farm }}$, after subtracting the expected quantity of electricity for drying and irrigation is calculated (named 'electricity rest') and assigned to the milk production, $C_{\text {milk }}$, where the larger part of the farm's electricity consumption occurs, differing according to number of milk producing unit, (MPU) where 1 MPU corresponds to l yearcow +1 heifer.

$E_{\text {plant }}+F_{\text {plant }}$

Predictions of physical input and output for single organic and conventional crop enterprise models are based on the farm registrations. Each input item is checked statistically for systematic differences between soil type and farming system, and the models are designed accordingly. Thus, for instance, the fertilizer and pesticide levels in conventional crops are not significantly different on clay and sandy soils while there are differences in the amounts of manure applied to organically and conventionally grown crops. Crop yields, $F_{\text {plant }}$, are analyzed by Halberg and Kristensen (in press) to test for dependency of farming systems, soil types and a regression variable expressing climatic differences. Farm-specific and crop-specific values of the regression variable are estimated using a crop growth simulation model to simulate potential yields for each farm and year. This way, differences between farms and years in water supply (precipitation and soil water retention capacity), temperature and radiation are corrected (Halberg and Kristensen, in press). From the regression equations, organic and conventional crop yields are predicted for clay soils and for sandy soils with and without irrigation. ${ }^{\dagger \dagger}$

$E_{\text {milk }}$

Differences in yield between organic and conventional dairy herds can be explained by known principles about the relationships between breed, stable, feeding and yield for a given herd (Kristensen, 1995; Kristensen and Kristensen, in press). It was concluded that the only general difference was due to feeding.

${ }^{\dagger+t}$ At a given input level, the energy productivity depends on the yields. The conventional crop yields and the differences between soil types are comparable with field trial gross yields on the National Institutc of Plant Science cxperimental stations (Halberg et al., 1995). Moreover, it is concluded that the yield differences between organic and conventional crops are generalizable within Danish mixed dairy farms. The actual yield on a given farm depends, however, on factors not accounted for in the models, for instance the farmer's skill. Thus, a certain variation in energy productivity exists within conventional as well as organic crops and within years as a consequence of yield variations. A $10 \%$ higher spring-sown grain and grass-clover yield on irrigated soils for instance would also increase energy productivity $10 \%$ assuming unchanged input but would not, however, change the relation between organic and conventional systems. 
$M_{\text {plant }}$

The main elements $A_{\text {plant }}, B_{\text {plant }}, C_{\text {plant }}, C F_{\text {plant }}, D_{\text {plant }}, E_{\text {plant }}$, and $F_{\text {plant }}$ are used to synthesize the model $M_{\text {plant }}$ for the composition of energy and production of yields in different cropping systems. The composition of the direct energy is shown first, then the composition of the indirect energy. The total energy input measured in megajoules is then related to the crop yield. Energy price is calculated as total energy input in megajoules per unit of output (kilogram or Scandinavian Feed Unit, where 1 SFU in fodder beets or silage corresponds to the feeding value for cows of $1 \mathrm{~kg}$ barley).

$M_{\text {milk }}$

$A_{\text {milk }}, B_{\text {milk }}, C_{\text {milk }}, D_{\text {milk }}, E_{\text {milk }}$ and $M_{\text {plant }}$ are used to synthesize models, $M_{\text {milk }}$, for the composition of energy and production of yields in different milk production systems. The models show the direct energy use, the composition of the indirect food, and the energy used for buildings. The energy price for milk production is calculated as total fossil energy input divided by total yield quantity in kilograms or Scandinavian Fecd Units.

\section{RESULTS}

\section{Energy utilization in the crop enterprises}

Tables 2-4 show separate models for three crop types on the three soil types. In addition, the energy price for winter-sown grain and whole crop silage is shown. Diesel use for spring-sown grain production (Table 2) is almost equal in the two systems. In organic production, more diesel is used in total for the handling of manure, especially because dry manure requires more energy to handle. The term 'maintenance' of the organic grain crop includes weed harrowing; while in the conventional system, diesel is used to spread fertilizer and pesticides. 'Diesel not accounted for' comprises $47 \%$ of total diesel use calculated from standard values (see Discussion). The fertilizer supply in conventional spring-sown grain crops was not significantly dependent on soil types and is the main reason for a higher total energy use compared with organic crops in the models. Fnergy costs for machines are almost equal in the two systems and on non-irrigated soils comprise 19 and $30 \%$ of total energy costs in conventional and organic crops, respectively. Though the yields are 700 $1100 \mathrm{~kg} \mathrm{ha}^{-1}(21-25 \%)$ higher in conventional grain production than on organic farms, the energy price is also higher in conventional production on all soil types (6-22\%), with the smallest difference on irrigated sandy soils.

Organic grown crops require less fossil energy than the conventional crops on the same soil type in all models. Though yields are also lower for all 
TABLE 2

Model for Energy Prices in Spring-Sown Grain and Winter-Sown Grain

\begin{tabular}{|c|c|c|c|c|c|c|}
\hline \multirow[t]{2}{*}{ Energy input $(M J)$} & \multicolumn{2}{|c|}{ Not irrigated sand } & \multicolumn{2}{|c|}{ Irrigated sand } & \multicolumn{2}{|c|}{ Clay } \\
\hline & $\begin{array}{l}\text { Conven- } \\
\text { tional }\end{array}$ & Organic & $\begin{array}{l}\text { Conven- } \\
\text { tional }\end{array}$ & Organic & $\begin{array}{l}\text { Conven- } \\
\text { tional }\end{array}$ & Organic \\
\hline & \multicolumn{6}{|c|}{ Spring-sown grain } \\
\hline Electricity, irrigation & & & 1971 & 1971 & & \\
\hline Electricity, drying & 246 & 195 & 318 & 239 & 311 & 239 \\
\hline Diesel, fluid manure & 459 & 197 & 459 & 197 & 459 & 197 \\
\hline Diesel, dry manure & 62 & 414 & 62 & 414 & 62 & 414 \\
\hline $\begin{array}{l}\text { Diesel, establishment } \\
\text { and maintenance }\end{array}$ & 1568 & 1399 & 1568 & 1399 & 1568 & 1399 \\
\hline Diesel, harvest, grain & 481 & 481 & 481 & 481 & 481 & 481 \\
\hline Diesel, transport, grain & 96 & 96 & 96 & 96 & 96 & 96 \\
\hline Diesel, not accounted for & 1208 & 1170 & 1208 & 1170 & 1208 & 1170 \\
\hline Sum, direct energy & 4120 & 3952 & 6163 & 5966 & 4186 & 3995 \\
\hline Seeds & 358 & 459 & 358 & 459 & 358 & 459 \\
\hline Mineral N & 3078 & & 3078 & & 3078 & \\
\hline Mineral P & 68 & & 68 & & 34 & \\
\hline Mineral K & 126 & & 126 & & 24 & \\
\hline Pesticides & 218 & & 218 & & 218 & \\
\hline $\begin{array}{l}\text { Limestone, stuff and } \\
\text { spreading }\end{array}$ & 150 & 150 & 150 & 150 & 150 & 150 \\
\hline Machines & 1936 & 1968 & 1936 & 1968 & 1936 & 1968 \\
\hline Sum indirect energy & 5934 & 2577 & 5934 & 2577 & 5798 & 2577 \\
\hline Sum energy & 10054 & 6529 & 12097 & 8543 & 9983 & 6572 \\
\hline Grain yield $\left(\mathrm{kg} \mathrm{ha}^{-1}\right)^{a}$ & 3400 & 2700 & 4400 & 3300 & 4300 & 3300 \\
\hline \multirow[t]{2}{*}{ Energy price $\left(\mathrm{MJ} \mathrm{kg}^{-1}\right)$} & 2.96 & 2.42 & 2.75 & 2.59 & 2.32 & 1.99 \\
\hline & \multicolumn{6}{|c|}{ Winter-sown grain } \\
\hline Energy price $\left(\mathrm{MJ} \mathrm{kg}^{-1}\right)$ & 2.63 & $2 \cdot 12$ & 2.48 & 2.47 & 1.98 & 1.56 \\
\hline
\end{tabular}

${ }^{a}$ Predicted yields.

crops in the organic system, the yield differences are smaller than the difference in energy input. For instance, the total energy costs in conventional clover-grass crops on clay and non-irrigated sandy soils are three to four times higher than in organic crops (Table 4). Yet conventional clover-grass yields are only $15 \%$ higher than organic, with a tendency for a greater difference on irrigated sandy soils, while the energy price is two to three times higher than the corresponding organic crops.

On conventional farms, a large part of the energy input comes from fertilizers, and this is the main reason for a higher total energy use compared 
TABLE 3

Model for Energy Prices in Fodder Beets

\begin{tabular}{|c|c|c|c|c|c|c|}
\hline \multirow[t]{2}{*}{ Energy input $(M J)$} & \multicolumn{2}{|c|}{ Not irrigated sand } & \multicolumn{2}{|c|}{ Irrigated sand } & \multicolumn{2}{|c|}{ Clay } \\
\hline & $\begin{array}{l}\text { Conven- } \\
\text { tional }\end{array}$ & Organic & $\begin{array}{l}\text { Conven- } \\
\text { tional }\end{array}$ & Organic & $\begin{array}{l}\text { Conven- } \\
\text { tional }\end{array}$ & Organic \\
\hline Electricity, irrigation & & & 3284 & 3284 & & \\
\hline Diesel, fluid manure & 1112 & 498 & 1112 & 498 & 1112 & 498 \\
\hline Diesel, dry manure & 150 & 1043 & 150 & 1043 & 150 & 1043 \\
\hline $\begin{array}{l}\text { Diesel, establishment } \\
\text { and maintenance }\end{array}$ & 1738 & 1890 & 1738 & 1890 & 1738 & 1890 \\
\hline Diesel, harvesting of root & 831 & 831 & 831 & 831 & 831 & 831 \\
\hline Diesel, harvesting of top & 553 & 553 & 553 & 553 & 553 & 553 \\
\hline Diesel, transport of root & 1019 & 1019 & 1019 & 1019 & 1019 & 1019 \\
\hline Diesel, transport of top & 1207 & 1207 & 1207 & 1207 & 1207 & 1207 \\
\hline Diesel, not accounted for & 2060 & 2263 & 2060 & 2263 & 2060 & 2263 \\
\hline Sum, direct energy & 8670 & 9304 & 11955 & 12588 & 8670 & 9304 \\
\hline Seeds & 22 & 32 & 22 & 32 & 22 & 32 \\
\hline Mineral N & 4674 & & 4674 & & 4674 & \\
\hline Mineral P & 85 & & 85 & & 0 & \\
\hline Mineral $\mathrm{K}$ & 174 & & 288 & & 0 & \\
\hline Pesticides & 403 & & 403 & & 403 & \\
\hline $\begin{array}{l}\text { Limestone, stuff and } \\
\text { spreading }\end{array}$ & 150 & 150 & 150 & 150 & 150 & 150 \\
\hline $\begin{array}{l}\text { Machines and soil } \\
\text { improvements }\end{array}$ & 2902 & 3134 & 2902 & 3134 & 2902 & 3134 \\
\hline Sum indirect energy & 8410 & 3316 & 8524 & 3316 & 8151 & 3316 \\
\hline Sum energy & 17080 & 12619 & 20478 & 15904 & 16821 & 12619 \\
\hline Yield (SFU ha $\left.a^{-1}\right)^{a}$ & 10240 & 9030 & 11270 & 9660 & 12180 & 10490 \\
\hline Energy price (MJ SFU ${ }^{-1}$ ) & 1.67 & 1.40 & 1.82 & 1.65 & $1 \cdot 38$ & $1 \cdot 20$ \\
\hline
\end{tabular}

a Predicted yields.

with organic crops. In conventional fodder beet crops (Table 3 ) and clovergrass crops (Table 4), fertilizers comprise $25-29 \%$ and $48-68 \%$ of total energy costs, respectively, and $27-33 \%$ in spring-sown grain crops (Table 2). On clay and sandy soils regularly supplied with manure, the yield responses are not sufficient to give the same energy cost as in organic crops.

The different types and amounts of manure in the conventional and organic crop models are not coincidental and reflect the higher stocking rate on conventional farms and the preference for deep litter stables and compost on the organic farms. The organic winter-grain and clover-grass crops (Tables 2 and 4) are supplied more manure than the conventional crops, reflecting the 
TABLE 4

Model for Energy Prices in Clover-Grass/Lucerne and Whole Crop Silage

\begin{tabular}{|c|c|c|c|c|c|c|}
\hline \multirow[t]{2}{*}{ Energy input $(M J)$} & \multicolumn{2}{|c|}{ Not irrigated sand } & \multicolumn{2}{|c|}{ Irrigated sand } & \multicolumn{2}{|c|}{ Clay } \\
\hline & $\begin{array}{l}\text { Conven- } \\
\text { tional }\end{array}$ & Organic & $\begin{array}{l}\text { Convent- } \\
\text { ional }\end{array}$ & Organic & $\begin{array}{l}\text { Conven- } \\
\text { tional }\end{array}$ & Organic \\
\hline & \multicolumn{6}{|c|}{ Clover-grass/lucerne } \\
\hline \multicolumn{7}{|l|}{$51 \%$ harvested } \\
\hline Diesel, fluid manure & 148 & 137 & 148 & 137 & 148 & 137 \\
\hline Diesel, dry manure & 20 & 288 & 20 & 288 & 20 & 288 \\
\hline $\begin{array}{l}\text { Diesel, establishment } \\
\text { and maintenance }\end{array}$ & 322 & 137 & 322 & 137 & 322 & 137 \\
\hline Diesel, harvest direct & 264 & 229 & 312 & 259 & 303 & 268 \\
\hline Diesel, harvest silage & 1445 & 1253 & 1710 & 1421 & 1662 & 1469 \\
\hline Diesel, harvest hay & 66 & 57 & 78 & 64 & 75 & 67 \\
\hline Diesel, transport direct & 67 & 58 & 80 & 66 & 77 & 68 \\
\hline Diesel, transport silage & 60 & 52 & 71 & 59 & 69 & 61 \\
\hline Diesel, transport hay & 9 & 7 & 10 & 8 & 10 & 9 \\
\hline Diesel, not accounted for & 345 & 236 & 367 & 251 & 363 & 255 \\
\hline Sum, direct energy & 2745 & 2454 & 8942 & 8516 & 3050 & 2759 \\
\hline Seeds & 65 & 94 & 65 & 65 & 65 & 94 \\
\hline Mineral N & 8550 & & 8550 & & 8550 & \\
\hline Mineral P & 272 & & 272 & & 272 & \\
\hline Mineral K & 432 & & 828 & & 306 & \\
\hline Pesticides & 72 & & 72 & & 72 & \\
\hline $\begin{array}{l}\text { Limestone, stuff and } \\
\text { spreading }\end{array}$ & 150 & 150 & 150 & 150 & 150 & 150 \\
\hline $\begin{array}{l}\text { Machines and soil } \\
\text { improvements }\end{array}$ & 1381 & 1134 & 1381 & 1134 & 1381 & 1134 \\
\hline Sum indirect energy & 10922 & 1378 & 11318 & 1349 & 10796 & 1378 \\
\hline Sum energy & 13667 & 3832 & 20260 & 9865 & 13846 & 4137 \\
\hline Yield (SFU ha $\left.{ }^{-1}\right)^{a}$ & 6000 & 5200 & 7100 & 5900 & 6900 & 6100 \\
\hline Energy price $\left(\mathrm{MJ} \mathrm{SFU}^{-1}\right)$ & 2.28 & 0.74 & 2.85 & 1.67 & 2.01 & 0.68 \\
\hline \multicolumn{7}{|l|}{$100 \%$ harvested for silage } \\
\hline Energy price $\left(\mathrm{MJ} \mathrm{SFU}^{-1}\right)$ & 2.72 & 1.19 & 3.27 & $2 \cdot 11$ & 2.43 & 1.11 \\
\hline \multicolumn{7}{|l|}{$100 \%$ grazed } \\
\hline \multirow[t]{2}{*}{ Energy price $\left(\mathrm{MJ} \mathrm{SFU}^{-1}\right)$} & 1.76 & 0.14 & $2 \cdot 36$ & $1 \cdot 11$ & 1.51 & 0.12 \\
\hline & \multicolumn{6}{|c|}{ Whole crop silage } \\
\hline Energy price $\left(\mathrm{MJSFU}^{-1}\right)$ & 2.98 & 2.62 & 2.82 & 2.63 & 2.39 & 1.97 \\
\hline
\end{tabular}

${ }^{a}$ Predicted yields. 
high fertilizer amounts applied to these crops and the generally higher nitrogen price expectations for manure not worked into the soil. Therefore, in the organic system the energy use arising from manure application is significantly higher for the two crops than in the conventional system.

In Fig. 3, the differences between the production systems for the five crop enterprises on the three soil types are presented. We see that:

1. the organically grown crops have in general a lower energy cost price than the conventional grown crops for each soil type and enterprise;

2. the crops are ranked differently according to energy prices within the two production systems;

3. in general, the clay soils show the lowest energy price and the irrigated sandy soils the highest energy price within cach enterprise and production system;

4. conventional grain crops -including whole crop silage - are the only crops where energy price is lower on irrigated sandy soils than on nonirrigated sandy soils.

Irrigation increases energy costs equally in organic and conventionally grown crops. Since the yield increase for non-irrigated sandy soils is highest in conventional crops, the difference in energy price between systems is smaller on irrigated sandy soils. The high potential yields on irrigated soils, assuming unlimited plant nutrient supply, are better utilized on conventional farms with access to mineral fertilizers, including the micro-nutrients that often are lacking on sandy soils.

In the conventional system, the fodder beets have the lowest energy price, while in the organic system clover-grass shows a significantly lower energy price than all other crops. However, this ranking depends on the proportion of the clover-grass crop harvested for silage, while this process is energy demanding. There are both direct and indirect energy cost related to the harvesting process. A change from about $50 \%$ harvested to $100 \%$ harvested and $100 \%$ grazed changes the energy price from 2.01 to 2.43 and $1.51 \mathrm{MJ} \mathrm{SFU}^{-1}$ on clay soils in the conventional system and from 0.68 to 1.11 and $0.12 \mathrm{MJSFU}^{-1}$ in the organic system (Table 4). Whole crop silage has almost the same energy price as spring-sown grain crops on clay and irrigated sand when the field is assumed to be grazed afterwards (Table 4).

\section{Energy utilization in the milk enterprises}

Table 5 show models for three different feeding rations for dairy production and the interactions between fodder quality and the need for purchased feed based on crop production on clay and irrigated sandy soils. The feeding 


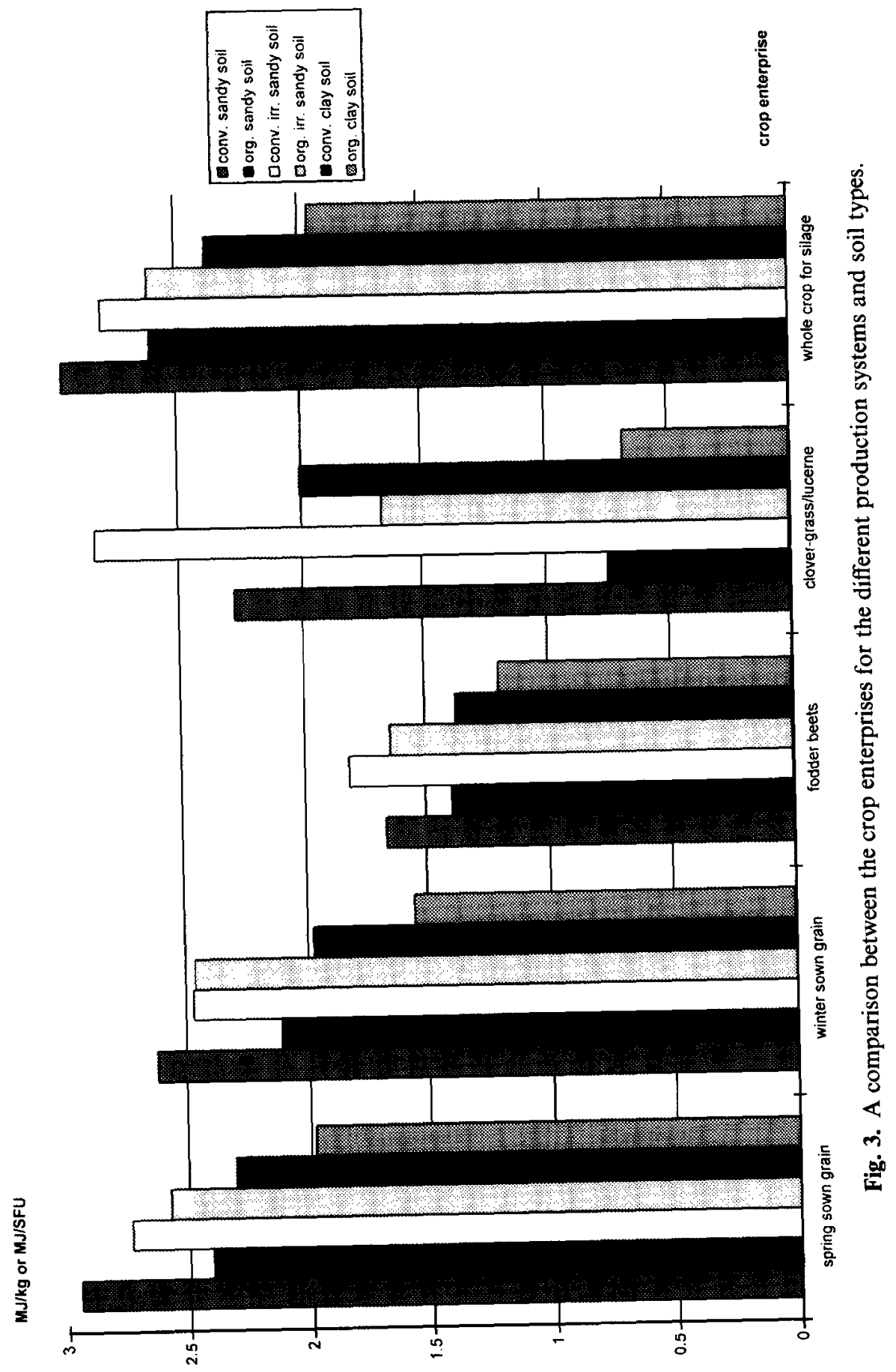


TABLE 5

Utilization of Fodder and Fossil Energy in the Dairy Production (Heavy Races)

\begin{tabular}{|c|c|c|c|c|c|c|}
\hline \multirow[t]{2}{*}{ Consumption pr. $M P U^{a}$} & \multicolumn{4}{|c|}{ Conventional } & \multicolumn{2}{|c|}{ Organic } \\
\hline & \multicolumn{6}{|c|}{ Organic diversified feeding ration } \\
\hline & & & Clo & y soils & & \\
\hline Direct energy & in $S F U$ & in $1000 \mathrm{MJ}$ & in $S F U$ & in $1000 \mathrm{MJ}$ & in $S F U$ & in $1000 \mathrm{MJ}$ \\
\hline Electricity (stable system) & & $6 \cdot 6$ & & $6 \cdot 6$ & & $6 \cdot 6$ \\
\hline \multicolumn{7}{|l|}{ Indirect energy } \\
\hline $\begin{array}{l}\text { Grassland and whole } \\
\text { crop fodder }\end{array}$ & 3200 & 6.7 & 4100 & 8.4 & 4100 & $3 \cdot 5$ \\
\hline Fodder beets & 1000 & 1.4 & 1000 & 1.4 & 1000 & $1 \cdot 2$ \\
\hline Grain & 600 & 1.4 & 800 & 1.9 & 800 & 1.6 \\
\hline Grass pellets & 0 & 0 & 0 & 0 & 0 & 0 \\
\hline Purchased fodder & 2400 & 13.9 & 1000 & 5.8 & 1000 & $4 \cdot 3$ \\
\hline Buildings etc. & & $3 \cdot 4$ & & 3.4 & & 3.4 \\
\hline In total & 7200 & 33.4 & 6900 & 27.5 & 6900 & $20 \cdot 6$ \\
\hline Yield milk $^{b}(\mathrm{~kg} \text { FCM })^{c}$ & 7300 & & 6950 & & 6950 & \\
\hline Increment ( $\mathrm{kg}$ meat) & 270 & & 260 & & 260 & \\
\hline \multirow[t]{2}{*}{ 'Milk unit' $\left(\mathrm{MJ} \mathrm{kg}^{-1}\right)^{d}$} & & 3.34 & & $2 \cdot 88$ & & $2 \cdot 16$ \\
\hline & \multicolumn{6}{|c|}{ Irrigated sandy soils } \\
\hline 'Milk unit' (MJ kg ${ }^{-1}$ ) & & 3.63 & & $3 \cdot 28$ & & $2 \cdot 66$ \\
\hline
\end{tabular}

'Milk unit' ( $\mathrm{MJ} \mathrm{kg}^{-1}$ )

Clay soils (substituting 500 SFU grain with 500 SFU grass pellets

${ }^{a} 1$ MPU (milk producing unit) $=1$ yearcow +1 heifer.

${ }^{b}$ See Kristensen (1995) and Kristensen and Kristensen (in press) for details concerning yield as a function of feeding system.

${ }^{c} \mathrm{ECM}=$ energy corrected milk.

${ }^{d}$ Meat production is converted to milk on energy basis (10:1).

strategy in the organic and in the conventional production was significantly different with regard to the composition of the feeding ration and the yields. The direct energy cost covering electricity is equal for all models because it is a residual with no significant differences in the crop models.

Using the farms own fodder is in general 'cheaper', from less than $1 \mathrm{MJ} \mathrm{SFU}^{-1}$ in the organic system to $2.3 \mathrm{MJ} \mathrm{SFU}^{-1}$ for conventional grown grain, than using imported fodder, which costs 4-6 $\mathrm{MJSFU}^{-1}$. The only exception is grass pellets, where the energy cost can rise up to about $20 \mathrm{MJ} \mathrm{SFU}^{-1}$-however, the major part of that energy is used outside the farm. Though yields are lower for the models with an organic feeding strategy, the energy prices are still better for the organic systems except when using grass pellets. 
For clay soils, a diversified organic feeding strategy with a high quantity of 'cheap' organic grass and a low quantity of imported fodder results in an energy cost of 2.16 compared with 3.34 for a diversified conventional production. A hypothetical conventional feeding ration with the same composition as a diversified organic one improves the energy price for conventional farms to $2.88 \mathrm{MJ} \mathrm{SFU}^{-1}$.

Comparing the energy prices from milk production based on crops grown on clay soils with those numbers from irrigated sandy soils $(2.66-3.63)$, it is obvious that not only feeding composition and production system but also soil type has a great impact on the energy utilization.

\section{DISCUSSION}

The restrictions on inputs in organic farming create a greater interdependency between the crop and the milk enterprise, resulting in fewer possibilities for the farmer to compose a feeding ration than in conventional farming. By conversion from conventional to organic production, it is possible for the conventional farmer to improve his energy utilization.

\section{Comparison with other investigations}

Nielsen and Rasmussen (1977) calculated the energy prices for several Danish farm enterprises in the middle of the 1970s. Comparing our model for spring-sown grain on clay in the conventional system with the Nielsen and Rasmussen calculations for barley, the major difference lies in the manufacturing of mineral fertilizer, where the energy consumption apparently has been halved since their calculation in the 1970s. The composition of the energy use in conventional milk production divided between direct energy, indirect energy for fodder and indirect energy for buildings is similar to the model from Nielsen and Rasmussen (1977). However, the energy cost for each input is lower and the quantity of input and output is higher for our models. Particularly, the energy cost for concentrated feed, covering $27 \%$ of the total energy in the models from Nielsen and Rasmussen, has been lowered.

A study by Bonny (1993) from France, in which the energy inputs and energy costs are visible, showed that French wheat production has improved energy utilization over the last 35 years. The result is a little higher energy price than the results from our study, primarily due to a higher energy consumption in mineral fertilizer manufacturing.

Studying farms in England and Wales, Vine and Bateman, 1981 (p. 113) found that "in terms of efficiency of energy use (measured by output per $£$ energy) organic farms and conventional farms are roughly on a par with a 
tendency if anything for organic farms to perform better". Pimentel et al. (1983) calculated that organic corn and spring wheat production would be $29-70 \%$ and $35-47 \%$ more energy efficient, respectively, than in conventional production systems.

Pimentel (1993) estimated higher energy input to conventional potato and maize production compared with organic production, mainly because of fertilizer energy costs being six times higher than the cost of supplying manure in the organic system. Since organic maize yields were assumed to be higher than conventional, the energy utilization naturally was better. Unfortunately, the relation between input factors and yields was not established using data from the same sources.

Since the core of the discussion here is actually the relation between levels of input and levels of yields, we suggest examining the question using datasets where the actual yields have been registered for specific input levels and combination of inputs, especially for the dairy production. Moreover, the yields for this type of model should be registered in environments reflecting most of the limits imposed by the overall system or production method investigated (i.e. crop rotation, fertilization and cultivation practices for the plant production; stable system, soil type and herd type for the dairy production).

A comparison of energy utilization between countries is difficult, because of differences in the climatic and technical conditions, as well as crop rotations affecting the amounts of inputs and the yields. Any broader interest in our results might be:

1. the methodological aspects of this work (i.e. systems modelling);

2. whether the results confirm the idea that energy costs can be lower in farming systems with low external input even if we have to accept lower yields.

\section{The correction factor}

On average, the farms used $47 \%$ more diesel in farm production than cxpected from the standards. This presently unexplained consumption varies between farms but there is no clear correlation with system. Therefore, the modelized diesel consumption for soil preparation, manuring, harvesting and other machine operations are multiplied by the factor 0.47 to give the item 'diesel not accounted for' in Tables 2-4. Naturally, standards cannot be expected to fit directly with observations from practice, so a confidence interval must be allowed. However, the systematic underestimation of real diesel consumption is problematic. Thus, the large CF indicates that one should be careful when basing crop energy productivity models on standard values only. 
Many of the standards are based on measurements of specialized plant production farms or experimental stations. However, more intense use and less repair of machines on dairy farms than on plant production farms may result in machines with a larger diesel consumption per operation and hectare (Birkjær et al., personal communication). The weather conditions also mean a great deal for energy consumption (Kristiansen and Nielsen, 1986). The busy dairy farmer might be forced to operate under worse weather conditions than is assumed when establishing standard values.

Moreover, on a farm there will always be some amount of diesel which cannot be assigned to a special enterprise. Since in our models all the diesel is assigned to the crop enterprises, this might explain a part of the difference between the registered and the expected consumption of energy. The use of small diesel trucks for the reloading of feedstuffs when feeding the animals might, on some farms, consume a significantly higher amount of diesel than expected from the standards used. In which case, the grain crops in our models have too high energy price, because the diesel not accounted for is divided among all crops in proportion with standard diescl use. On somc farms, large amounts of straw are handled throughout the autumn and winter seasons, which again ideally should burden the herds and not the single crop models. Further studies are needed to show whether this is linked with special types of feeding or stable systems in the dairy production.

Any detailed partition of the diesel not accounted for will have to await further research into these questions. However, for our purpose of modelling the consequences of different feeding and crop production strategies on dairy production energy utilization on farm level, it is less important whether some part of the diesel is used rather for the handling of roughage than for the field operations.

\section{Sensitivity analysis of energy expensive processes}

\section{Irrigation}

It is not possible to define the exact yield response per millimetre water irrigated in this study. However, assuming a linear dependency between irrigation quantity and yield for each production system on sandy soils, we can calculate the marginal energy price for the difference between irrigated and non-irrigated sandy soils for both systems (Table 6).

Irrigating the grass fields with $133 \mathrm{~mm}$ water gives a marginal energy price which is much higher than the average energy price for both production systems on sandy soils. For grain irrigated with $45 \mathrm{~mm}$, the marginal energy price is lower than the average energy price in the conventional system, whereas this is not the case in the organic system as discussed already. This indicates that by increasing the irrigation quantity on spring-sown grain and 
TABLE 6

The Marginal Effect of Irrigation on Non-Irrigated Sandy Soils for Spring-Sown Grain and Clover-Grass/Lucerne

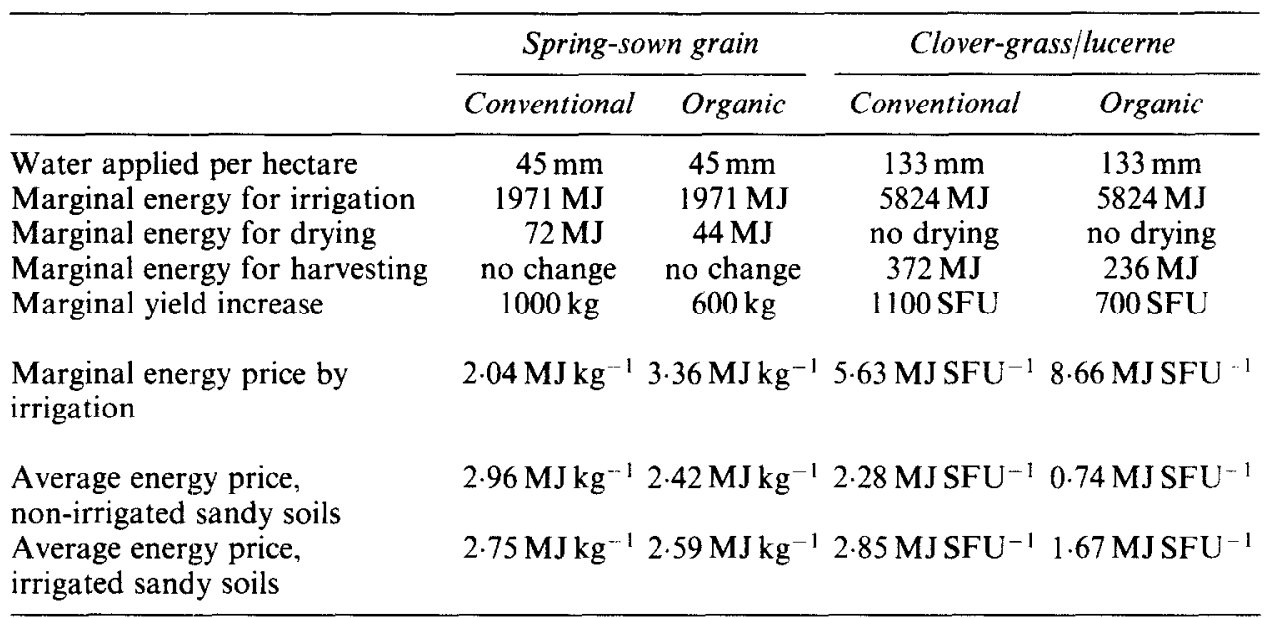

decreasing the irrigation quantity on clover-grass fields, the total energy utilization can be improved.

\section{Fertilizing}

Since fertilization accounts for a large part of conventional energy costs, the effect of a hypothetical reduction in fertilizer levels on the energy productivity is tested. It is not possible to define the exact yield response per kilogram nitrogen in the conventional crop yield models (Halberg and Kristensen, in press), therefore a precise marginal energy price cannot be calculated. However, under the assumption of unreduced yield, it is calculated which level of fertilizer will give the same average conventional energy price as the organic (Table 7). Based on the latest developments in advisory service fertilisation recommendations, the simulations leave out $\mathrm{P}$ and $\mathrm{K}$ fertilizer in springsown grain and fodder beets because of the large input of manure in these crops.

From Table 7 it appears that the same average energy price in conventional as in organic spring-sown grain theoretically can be reached by eliminating the mineral $\mathrm{P}$ and $\mathrm{K}$ and 16 and $36 \mathrm{~kg} \mathrm{~N} \mathrm{ha}^{-1}$ from the conventional input list for sandy and clay soils, respectively. The same calculation applied to winter grains but without changing $\mathrm{P}$ and $\mathrm{K}$ levels shows that the supply has to be decreased by 7.5 and $75 \mathrm{~kg} \mathrm{~N} \mathrm{ha}^{-1}$, respectively, on the conventional irrigating sandy and clay soil crops to equal the organic energy price of 2.47 and $1.56 \mathrm{MJ} \mathrm{kg}^{-1}$ grain. To decrease conventional fodder beets and grass-clover energy price to the levels at organic production will imply 
TABLE 7

Necessary Reductions in Fertilizer Input to Equal Conventional and Organic Energy Price

\begin{tabular}{|c|c|c|c|c|}
\hline & $\begin{array}{l}\text { Spring-sown } \\
\text { grain }\end{array}$ & $\begin{array}{l}\text { Winter } \\
\text { grain }\end{array}$ & $\begin{array}{l}\text { Fodder } \\
\text { beets }\end{array}$ & $\begin{array}{l}\text { Clover-grass/ } \\
\quad \text { lucerne }\end{array}$ \\
\hline & \multicolumn{4}{|c|}{ Clay soils } \\
\hline Conventional yield & $4300 \mathrm{~kg}$ & $6900 \mathrm{~kg}$ & 12180 SFU & 6900 SFU \\
\hline Organic energy price & $1.99 \mathrm{MJ} \mathrm{kg}^{-1}$ & $1.56 \mathrm{MJ} \mathrm{kg}^{-1}$ & $1.20 \mathrm{MJ} \mathrm{SFU}^{-1}$ & $0.68 \mathrm{MJ} \mathrm{SFU}^{-1}$ \\
\hline $\begin{array}{l}\text { Decrease in energy input to } \\
\text { equal organic energy price }\end{array}$ & $1383 \mathrm{MJ}$ & $2853 \mathrm{MJ}$ & $2146 \mathrm{MJ}$ & $9152 \mathrm{MJ}$ \\
\hline \multicolumn{5}{|l|}{ Decrease in fertilizer input pr. ha } \\
\hline $\mathbf{P}, \mathbf{K}$ & all & & & all \\
\hline & & / J Kg IIa & $50 \mathrm{kgna}$ & $220 \mathrm{~kg} \mathrm{na}$ \\
\hline \multirow[t]{2}{*}{$\% \mathrm{~N}$ decrease } & $43 \%$ & $48 \%$ & $46 \%$ & $100 \%$ \\
\hline & \multicolumn{4}{|c|}{ Irrigated sandy soils } \\
\hline Conventional yield & $4400 \mathrm{~kg}$ & $6400 \mathrm{~kg}$ & $11270 \mathrm{SFU}$ & 7100 SFU \\
\hline Organic energy price & $2.59 \mathrm{MJ} \mathrm{kg}^{-1}$ & $2.47 \mathrm{MJ} \mathrm{kg}^{-1}$ & $1.65 \mathrm{MJSFU}^{-1}$ & $1.67 \mathrm{MJ} \mathrm{SFU}^{-1}$ \\
\hline $\begin{array}{l}\text { Decrease in energy input to } \\
\text { equal organic energy price }\end{array}$ & $815 \mathrm{MJ}$ & $285 \mathrm{MJ}$ & $2003 \mathrm{MJ}$ & $8427 \mathrm{MJ}$ \\
\hline \multirow{2}{*}{$\begin{array}{l}\text { Decrease in fertilizer input pr. ha } \\
\mathrm{P}, \mathrm{K} \\
\mathrm{N}\end{array}$} & & & & \\
\hline & $\begin{array}{l}\text { all } \\
16 k_{0} a^{-1}\end{array}$ & $75 \mathrm{kgha}^{-1}$ & $\underset{53 \operatorname{kaha}^{-1}}{\text { all }}$ & $102 \mathrm{kgha}^{-1}$ \\
\hline & & & & \\
\hline$\% \mathrm{~N}$ decrease & $20 \%$ & $5 \%$ & $43 \%$ & $86 \%$ \\
\hline
\end{tabular}

reductions of roughly 45 and $100 \%$, respectively, in fertilizer input with no yield reduction.

These relatively high reductions in fertilizer input in the fodder crops probably violate the assumption of unchanged yields, making even further input reductions necessary to reach the organic energy price levels, if that should be a goal. The relatively low yield differences in spite of large input differences between organic and conventional fodder crops indicate a low nitrogen fertilizer response, which might be due to the higher clover content in organic grass-clover crops (Halberg and Kristensen, in press) and a higher utilization of nitrogen mineralized from soil and manure in the organic fodder beets (Halberg et al., 1995).

For the conventional clay soil grain crops to equal the energy price of organic crops, they will need a roughly $45 \%$ fertilizer reduction, which probably also will decrease yields. The smallest fertilizer changes necessary to equal the energy price in the two systems are found for irrigated grain crops on sandy soils, reflecting the higher yield differences found in these soils. 
The fertilizer levels vary between the studied farms but are not on average different from normal practice on Danish dairy farms, and the average $93 \mathrm{~kg}$ $\mathrm{N}$ ha ${ }^{-1}$ spring-sown grain used in the models probably more than secures most of these crops against lack of nitrogen (Halberg et al., 1995). The difference in organic and conventional grain crop energy price on irrigated sandy soils is, according to our models, a question of only 16 versus $7.5 \mathrm{~kg} \mathrm{~N}$ $\mathrm{ha}^{-1}$ (Table 7). Therefore, conventional farms with a lower energy price on irrigated crops compared with organic grain crops might well exist. The same is not likely for clay soil grain crops, given the larger difference in energy productivity. Even if conventional yields will decrease slightly with a small decrease in $\mathrm{N}$ input, a higher energy price in grain crops may be reached at an intermediate level between organic and the present conventional system, especially on irrigated soils.

Halberg and Kristensen (in press) found that the organic-conventional yield difference in spring-sown grain is lower than expected from Danish experimentally derived fertilizer and pesticide yield responses. It is suggested that the main reasons for that are higher $\mathrm{N}$ mineralization on organic soils due to larger grass clover area in crop rotation, increased utilization of mineralized $\mathrm{N}$ from soil and manure in organic crops, and interactions between $\mathrm{N}$ supply levels and crop yield losses from plant pests. It shall be noted that the organic grain crops benefit from a systematically larger proportion of grass-clover in the rotation, which is why neither the $\mathrm{N}$ response curve nor the maximum on a (theoretical) energy price curve can be calculated by interpolation in the crop-level models. This again underlines the importance of starting from the farm level in this type of analysis.

\section{The matter of feeding strategy}

An organic feeding strategy is not necessarily energy efficient. Grass pellets is a widespread fodder both in organic and conventional dairy production. It is a flexible winter fodder - easy to store and handle. However, substituting $500 \mathrm{SFU}$ grain with $500 \mathrm{SFU}$ grass pellets raises the energy price in organic milk production from 2.16 to about $2.92 \mathrm{MJ} \mathrm{kg}^{-1}$ 'milk units'. So, with a substitution for $7 \%$ of the fecding ration, the total encrgy saved by farming organically is lost, when compared with the same feeding ration but based on conventional crop production.

\section{Transport}

Another interesting point is the matter of transport. The energy use differs according to transport medium, type of product and origin of the product. For soy beans shipped about $10000 \mathrm{~km}$ from the USA, the transport covers $20 \%$ of the total energy use. For fluid ammonium $\left(\mathrm{NH}_{3}\right)$ shipped about $500 \mathrm{~km}$ from Norway, the transport covers $3 \%$, whereas the transport part 
for rapeskakes produced in Denmark and transported $75 \mathrm{~km}$ using a trailer is about $11 \%$. The less concentrated the product (the higher the content of water) and the longer the distances, the more the transport matters.

\section{Land use}

Improvements in energy utilization are to some extent substituted by a higher consumption of land. In our models, a relatively high energy price was followed by a relatively good land use ratio and vice versa. The most efficient method to save energy, however, is to produce pure plant products regardless of the type of production system. Suppose we convert from mixed dairy production to pure crop production regardless of the type of production system, and with the same total production of feed units for human nutrition. This will reduce the energy consumption to $15-20 \%$ and reduce the consumption of land to $35-40 \%$ of the original mixed production of milk, meat and crops. Therefore, a balancing is necessary in a total evaluation of the performance of resource utilization of different production systems.

\section{Perspectives}

Energy utilization in crop and milk production depends on farmers' decisions concerning use of inputs and their effects on output. Therefore, this is partly a question of management. The models are designed for use by scientists, advisors and farmers to evaluate the energy-related consequences of different production strategies. It might be interesting for some farmers to evaluate the possibilities for lowering the energy prices in their crop and milk production. The organic crops might be feasible fix points for such an evaluation of possible yields and energy prices with low fertilizer input. In particular, for the grass-clover crops it would be possible for conventional farmers to mimic the low input system, increasing the overall energy productivity for the farm. Changing feeding strategy and using the organic diversified feeding ration is a proper alternative for farmers to improve their encrgy utilization in conventional dairy production.

Inside each production system there might also be ways of improving energy productivity. The irrigation strategy on sandy soils could be changed to irrigate less on clover-grass/lucerne crops and rely more on the compensatory growth of grass. There are also possibilities for reducing harvest energy use on grass-clover, leaving more of the crop for grazing. Also, within crop rotation, changes to grow crops with high energy productivity could be adopted (e.g. substituting whole crop silage with clover-grass). Of course, these questions cannot be evaluated from the crop rotation level alone, as they influence and are influenced by the feeding strategy of the herd. From 
the herd point of view, there is a contradiction between the idea of reducing clover-grass irrigation - thus, accepting a more unpredictable and less stable grass production--and the idea of saving harvesting energy by increasing the grass uptake from grazing. From a farm perspective, reducing the feeding intensivity improves the energy utilization in dairy production, leaving a greater quantity of plant products for sale, thereby improving the energy utilization for the farm as a whole.

Another reason why changes in crop production should be evaluated at the farm level is that lower yields per hectare might have to be compensated for by less cash crop production or by increased feed purchases. This again might have consequences for milk or meat energy cost. Take for example a conventional dairy farmer who, as suggested already, converts to 'organic' white-clover-based clover-grass fields and hereby increases grass energy productivity $100 \%$ while accepting $15 \%$ lower yields per hectare. If the farmer will not accept any reductions in milk production per hectare, he/she might start to purchase dried grass pellets (with an energy cost of 10-20 $\mathrm{MJ} \mathrm{SFU}^{-1}$ ) in amounts that partly counterbalance the saved energy from the reduced fertilization.

It is, therefore, the intention that the crop and milk models be used as part of a farm-level model to facilitate simulation by researchers and advisors of the energetic consequences of different production strategies.

Still, drastic action such as moving to more fertile land (i.e. clay soil) would tend to improve the energy utilization even more than converting to organic production methods on sandy soils (Fig. 3). This is not the case for clover-grass crops where the energy price is much lower in the organic production system than even in conventional clay soil crops, since clover-grass covers on average $40 \%$ of the rotation area on organic farms.

However, a much more efficient method to save energy than changing from a conventional dairy production system to an organic one is to produce pure plant products, thereby avoiding the low efficiency $(5-40 \%)$ with which an animal converts its food into biomass (Hall et al., 1992). This is a drastic, perhaps unrealistic, action which needs more research and investigation.

As pointed out by Spedding and Walsingham (1975), Pimentel (1980), Hall et al. (1992), Pimentel (1993) and Giampietro et al. (1994), the measures for energy utilization are excellent parameters for evaluating production intensity because energy is a necessary input for every production process. This has been confirmed in our data where the organic system had fewer and lower quantities of energy input but also lower output. Thus, as an example of the 'alteration of patterns of energy flows' mentioned in Giampietro et al. (1994), one might think of organic farming as a systematic replacement of fossil fuel in $\mathbf{N}$ fertilizer production with solar-driven $\mathbf{N}$ fixation in legumes. 


\section{CONCLUSION}

Most organic crop models show an energy price lower than or equal to that of conventional crops. Thus, lowering input intensity does not generally seem to have negative impacts on crop level energy utilization. Fertilizer sensitivity analysis indicates that the lowest energy price in grain crops would be found at moderate fertilizer levels (especially on irrigated sand). Still, organic fodder crops show clearly lower energy prices than conventional crops. The prices for organic production as a proportion of the conventional production are from 32 to $59 \%$ for clover-grass and from 84 to $91 \%$ for fodder beets, primarily because the high fertilizer energy cost of conventional crops is not compensated for by correspondingly higher yields. Since grass-clover comprise on average $40 \%$ of the total rotation area on the studied organic farms, the average energy cost per organically produced SFU was lower than for the conventional fodder.

Using a diversified organic feeding ration with a lower intensivity and thereby lower yields than the conventional one results in a better energy utilization. A composition with the organic feeding strategy has $30 \%$ greater quantities of 'cheap' clover-grass and $50 \%$ smaller quantities of 'expensive' purchased feed than the conventional one. However, the more energy efficient feeding strategy in organic production is dependent on the costs in the crop production. Using the organic feeding strategy but based on conventional crop production can improve the conventional production. Conversely, substituting $7 \%$ of the feeding ration of grain with 'expensive' grass pellets raises the energy price with $34 \%$, thereby making the organic feeding strategy based on conventional crop production even more favorable.

An average of $47 \%$ more diesel was used than predicted from standard values. This large $\mathrm{CF}$ suggests that evaluations of crop production based on standard values alone underestimate energy prices. Modelling based on a combination of experimentally derived standards and collected data from private farms, broken down to enterprise level, seems an interesting approach to study the effect of different production intensities on energy utilization. This methodology also permits the researcher to identify limits and rules in the subsystem imposed by the overall farming system level. For example, the different amounts and partition of manure between crops in the two systems and the larger percentage of the most energy efficient crop, clover-grass, in the organic crop rotations compared with conventional rotations.

The crop and milk models are used to form farm-level models for the simulation of the overall effect of different production intensities on milk energy price considering interactions between fodder production, feed purchases and milk production. Though the models presented apply to a 
limited number of farms and to specific years, the standardization of energy use and yields allow for generalizing the results to other mixed dairy farms if one corrects for potential yields and the use of manure, race and stable type.

\section{ACKNOWLEDGEMENTS}

The authors wish to thank the following persons for valuable help, comments and information concerning some of the figure on standard diesel use: Villy Nielsen, Department of Agricultural Engineering and Production Systems; Eilif Jakobsen, Bioteknisk Institut; K. Ole Birkjær, Jens Jonsen Høy and E. Schiønning-Madsen, Landbrugets Rådgivningscenter; Mogens Kjeldahl, Maskinstationtjenesten; Poul Andersen, Danmarks Tekniske Højskole; Lars Krejbjerg, Dansk Landbrugs Grovvareselskab; Jens Peter Jensen, Korn- og Foderstofkompagniet; Hans Jørgensen, Danmarks Rederiforening; Ole Hansen, Danske Vognmænd.

\section{REFERENCES}

Bøckman, O. C., Kaarstad, O. L., Ole H. and Richards, I. (1991): Landbruk og gjødsling. Mineralgjødsel i perspektiv. Norsk Hydro a.s., Norge.

Bonny, S. (1993) Is agriculture using more and more energy? A French case study. Agricultural Systems 43, 51-66.

Bowers, W. (1992) Agricultural field equipment. In: Energy in Farm Production, ed. R. C. Fluck. Energy in World Agricultural, 6. Elsevier, pp. 117-129.

Daly, H. E. and Cobb, J. B., Jr. (1989) For the Common Good. Redirecting the Economy Toward Community, the Environment, and a Sustainable Future. Beacon Press, Boston.

Danmarks Statistik (1990a) Agricultural Statistics (several years). Danmarks Statistik, Copenhagen, Denmark.

Danmarks Statistik (1990b) National Account Statistics (several years). Danmarks Statistik, Copenhagen, Denmark.

Fluck, R. C. (1979) Energy productivity: a measure of energy utilization in agricultural systems. Agricultural Systems 4, 29-37.

Fluck, R. C. (1992) Energy Analysis for Agriculture. In R. C. Fluck, ed.: Energy in Farm Production. Energy in World Agriculture, 6. Elsevier, pp. 45-52

Giampietro, M., Bukkens, S. G. F. and Pimentel, D. (1994) Models of energy analysis to assess the performance of food systems. Agricultural Systems 45, 19-41.

Halberg, N. and Kristensen, I. S. (in press) Expected yield loss when converting to organic dairy farming in Denmark. Biological Agriculture and Horticulture.

Halberg, N., Kristensen, E. S. and Kristensen, I. S. (1995) Nitrogen turnover on organic and conventional mixed farms. Journal of Agriculture and Environmental Ethics 8, 30-51.

Hall, C., Cleveland, A. S., Cutler J. and Kaufmann, R. K. (1992) Energy and Resource Quality: The Ecology of the Economic Process. University Press of Colorado, Colorado. 
Jones, M. R. (1989) Analysis of the use of energy in agriculture. Approaches and Problems. Agricultural Systems 29, 339-355.

Kristensen, T. (ed.) (1993) Studier i kvægproduktionssystemer. 722. Report from the National Institute of Animal Science, Foulum, Denmark.

Kristensen, E. S. (1995) Økologisk landbrug med udgangspunkt i kvægbedriften. Intern Rapport nr. 42 fra Statens Husdyrbrugsforsøg.

Kristensen, E. S. and Kristensen, I. S. (in press) Analysis and simulation modelling of the production in Danish organic and conventional dairy herds. Livestock Production Science.

Kristensen, T. and Østergaard, V. (eds) (1992) Studier i kvægproduktionssystemer. 714. Report from the National Institute of Animal Science, Foulum, Denmark.

Kristiansen, P. S. and Nielsen, V. (1986) Energiforbrugets afhængighed af redskabsstørrelse og køreteknik ved traktorkørsel. Beretning nr. 27 fra Statens Jordbrugstekniske Forsøg.

Leach, G. (1976) Energy and food production. IPC Science and Technology Press, Guildford, England.

Nielsen, V. (1991) Energiforbrug ved håndtering af gras. Statens Jordbrugstekniske Forsøg, Horsens, Beretning nr. 47.

Nielsen, V. and Larsen, E. K. (1991) Mekanisk ukrudtsbekæmpelse i økologisk jordbrug. I. Litteraturstudier. Kortlægning. Foreløbige resultater. Orientering nr. 73, Statens Jordbrugstekniske Forsøg. Horsens, Denmark.

Nielsen, A. H. and Rasmussen, S. (1977) En kortlægning af den primære jordbrugssektors energiforbrug. Landbrusøkonomiske Studier, 7. Økonomisk Institut, Den kgl. Veterinær -og Landbohøjskole, Copenhagen.

Østergaard, V. (ed.) (1990) Studier i kvægproduktionssystemer. 681. Report from the National Institute of Animal Science, Foulum, Denmark.

Østergaard, V. (ed.) (1991) Studier i kvægproduktionssystemer. 699. Report from the National Institute of Animal Science, Foulum, Denmark.

Parsby, M. and Fog, M. M. (1984) Den primare jordbrugssektors energiforbrug 1982/ 83-status of perspektiver. Institute of Agricultural Economics, Report no. 18, Copenhagen.

Pick, E., Norén, O. and Nielsen, V. (eds) (1989) Energy consumption and inputoutput relations of field operations. CNRE Study no. 3. FAO, Rome.

Pimentel, D. (ed.) (1980) Handbook of Energy Utilization in Agriculture. CRC Press, Boca Raton, FL.

Pimentel, D. (1993) Economics and energetics of organic and conventional farming. Journal of Agricultural and Environmental Ethics 6, 53-61.

Pimentel, D., Hurd, L. E., Bellotti, A. C., Forster, M. J., Oka, I. N., Sholes, O. D. and Whitman, R. J. (1973) Food production and the energy crisis. Science 182, 443-449.

Pimentel, D., Berardi, G. and Fast, S. (1983) Energy efficiency of farming systems: organic and conventional agriculture. Agriculture, Ecosystems and Environment 9, 359-372.

Pimentel, D., Herdendorf, M., Eisenfeld, S., Olander, L., Carroquino, M., Corson, C., McDade, J., Chung, Y., Cannon, W., Roberts, J., Bluman, L. and Gregg, J. (1994) Achieving a secure energy: environmental and economic issues. Ecological Economics 9, 201-219.

Refsgaard, K. (1992) Grundlag for beregning af energiindsatsen ved fremstilling af hjælpestoffer på primære landbrugsbedrifter. Calculation of energy use in 
manufacturing of inputs to dairy farms. Working paper, National Institute of Animal Science.

Schroll, H. (1994) Energy-flow and ecological sustainability in Danish agriculture. Agriculture, Ecosystems and Environment 51, 301-310.

Smil, V., Nachmann, P. and Long, T. V., II (1983) Energy Analysis and Agriculture. An application to U.S. Corn Production. Westview Press, Boulder, Colorado.

Sørensen, J. T. and Kristensen, E. St. (1993) Systemic modelling: a research methodology in livestock farming. In: Global Appraisal of Livestock Farming Systems and Study of Their Organizational Levels, eds G. Gibon, G. R. Mathon and B. Vissac. Proceeding CEC-Seminar EUR 14479, pp. 45-57. Luxembourg.

Spedding, C. R. W. and Walsingham, J. M. (1975) The production and use of energy in agriculture. Journal of Agricultural Economics 27, 19-30.

Steinhart, J. S. and Steinhart, C. E. (1974) Energy use in the U.S. food system. Science 184, 307-316.

Vine, A. and Bateman, D. (1981) Organic Farming Systems in England and Wales: Practice, Performance and Implications. Department of Agricultural Economics. University College of Wales, Aberystwyth.

Wagstaff, H. (1987) Husbandry methods and farm systems in industrialized countries which use lower levels of external inputs: a review. Agriculture, Ecosystems and Environment 19, 1-27.

\section{APPENDIX}

TABLE A1

Conditions Underlying the Results From the Energy Analysis

\begin{tabular}{|c|c|c|}
\hline \\
\hline \multicolumn{3}{|l|}{$\frac{\text { Conditions }}{\text { Transport factor }}$} \\
\hline Skifte factor & 1.47 & \\
\hline Diesel oil & $35 \cdot 9$ & MJ litre $^{-1}$ \\
\hline Lubricating oil & $38 \cdot 7$ & MJ litre ${ }^{-1}$ \\
\hline Electricity & 9.52 & $\mathrm{MJ} \mathrm{kwh}^{-1}$ \\
\hline Nitrogen & 38 & $\mathrm{MJ} \mathrm{kg}^{-1}$ pure $\mathrm{N}$ \\
\hline Phosphorus & 17 & $\mathrm{MJ} \mathrm{kg}^{-1}$ pure $\mathrm{P}$ \\
\hline Kalium & 6 & $\mathrm{MJ} \mathrm{kg}^{-1}$ pure $\mathrm{K}$ \\
\hline Pesticides & $40 \cdot 3$ & $\mathrm{M} J \mathrm{~kg}^{-1}$ \\
\hline Limestone & 0.21 & $\mathrm{MJ} \mathrm{kg}^{-1}$ \\
\hline Soybean & $6 \cdot 18$ & $\mathrm{MJ} \mathrm{kg}^{-1}$ \\
\hline Grass pellets & 15 & MJ SFU $^{-1}$ \\
\hline Diesel, fluid manure & 0.41 & litre ${ }^{1}{ }^{1}$ fluid manure \\
\hline Diesel, dry manure & 1.05 & litre $t^{-1}$ dry manure \\
\hline Diesel, limestone & 1.25 & litre $\mathrm{ha}^{-1}$ \\
\hline Electricity, irrigation & 4.6 & kwh mm ${ }^{1}$ water ha 1 \\
\hline Electricity, drying & 0.38 & $\mathrm{kwh} 1.2 \mathrm{~kg}^{-1}$ evaporated water \\
\hline Lubricating oil, field operations & $0.62 \%$ & litre litre ${ }^{-1}$ diesel oil \\
\hline
\end{tabular}




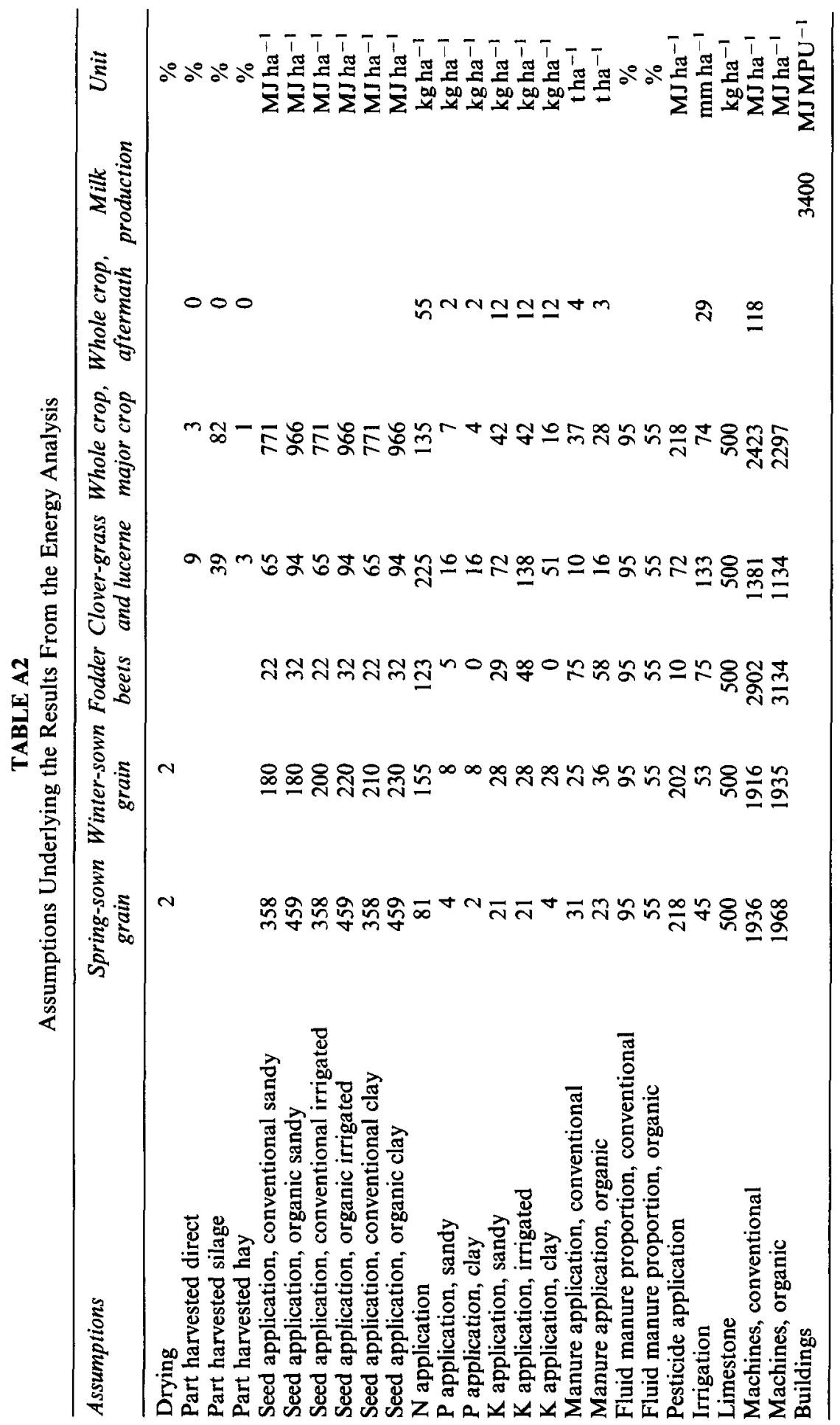

